\title{
Analysis of the Planning and Development of Employee Career Paths in the Job Placement for a Supervisor Position in Badan Kepegawaian Negara
}

\author{
Yani Rosyani \\ Faculty of Social and Political Sciences \\ Universitas Indonesia \\ Depok, Indonesia: \\ yani.rosyan@gmail.com
}

\author{
Amy Yayuk Sri Rahayu \\ Faculty of Social and Political Sciences \\ Universitas Indonesia \\ Depok, Indonesia \\ amy_soeroso@yahoo.com
}

\begin{abstract}
This study aims to analyze planning and development of employee career path in job placement for supervisor position in Badan Kepegawaian Negara (BKN) Indonesia. This study uses postpositivisme approach. The result shows there is not yet alignment between Career Planning and Career Management in the State Employment Agency, employee career planning is unplanned and does not have a clear career purpose because career management in BKN does not set out an employee career path that is in accordance with qualification and competence. The career management in BKN has not composed an employee career pattern that is in accordance with the potential of the employees and the needs of the organization. Therefore, job placement for supervisor position does not have correlation with planning and development of employee or even organizations needs and goals.
\end{abstract}

Keywords-career planning, career development, career management, job placement

\section{INTRODUCTION}

The Indonesian State Employment Agency (BKN) adopts an organization structure that draws from the work plan set out in the Regulation of the Head of the State Employment Agency issued by the Head of BKN after obtaining a written approval from the Minister in charge for State Apparatus Reforms (Regulation of the Head of BKN Number 19 Year 2014 on the organization and work plan of BKN). The formation of Civil Service is the process by which the quota and arrangement of Civil Service positions which are required to carry out the main duties are determined by the main authority. The formation is decided for a certain period of time based on the type, the nature, and the work load that must be carried out. Based on the table of the Formation of Structural Positions in the State Employment Agency from 2012 to 2015, the Formation of Echelon IV Position or the Head of the Sub-Division or the Head of the Section or the position of supervisor never meet the target of the required numbers in the formation. The Republic of Indonesia's Law Number 5 of the Year 2014 on
ASN Article 131 states that the echelon IV position commensurates with the Supervisor Position.

In 2014, BKN initiated organization structure slimming processes that are in accordance with the Regulation of the Head of BKN (Perka BKN) Number 19 of the Year 2014 on the Organization and Work Plan of BKN following the Republic of Indonesia's Law Number 5 of the Year 2014 on Civil State Apparatus (ASN). From the table, it is indicated that the formation in 2014 decreased from the previous year, but the formation in 2014 and 2015 remained unmet. The impact of the unfulfilled formation influences the performance of the organization, as many supervision positions are vacant. Thus, the main duty and function of the vacant supervisor position unit are not carried out as they should be.

Based on the availability of HR in BKN based on education level from 2012 to 2015, the number of employees with Undergraduate, Master's, and Doctorate degrees from 2012 to 2015 experienced an increase, and the availability is adequate for meeting the formation of the supervisor position that requires candidates to have at least an Undergraduate degree.

The Selection Process for the echelon IV position or the Supervisor position formation is carried out based on the needs of the organization. For the selection of the echelon IV position, it is carried out internally by $\mathrm{BKN}$ with candidates coming from the internal employment of BKN. The requirements for candidates of Echelon IV or the Supervisor Position in BKN are: (1) the minimum education level is Undergraduate level; (2) the maximum age is 54 years old; (3) the minimum rank/status is Penata Muda Level I / IIIb; (4) the person has not been subject to any disciplinary punishment in the past five years; (5) all the elements of the DP3 Assessment in the past two years have been assessed as Good at the minimum; (6) candidates who have been proposed receive a Good assessment in terms of loyalty and further potential from their superiors.

Based on the aforementioned requirements, it is expected that the available Formation will be filled in by the right person for the right position. In the State Employment Agency, the 
formation for the Supervisor Position or echelon IV from 2012 to 2015 was not always achieved. This is a seemingly contradictory fact because of the availability of employees in BKN who have met the general criteria to partake in the selection for the Supervisor Position. This then brings up the question: How are the employee career paths planned in the career management in the State Employment Agency? And how are the employee career paths planned and developed to meet the Supervisor Position in the State Employment Agency? The purpose of this research is to analyze career planning in the career management in the State Employment Agency and to analyze the planning and the development of employee career paths in meeting the formation of the Supervisor Position in the State Employment Agency.

When embarking on a career path, an employee will be faced with numerous challenges. For a secure career path, an employee must always improve their ability in terms of knowledge, skills, and attitude, depending on what is required of the employee's rank or position. According to career development, two interrelated aspects that influence one another are career planning and development are: "career planning and development giving employee assistance to develop realistic career goals and the opportunities to realize them." [1] To analyze the planning and the development of employee career in fulfilling the formation of the supervisor position in BKN, the author uses the theory from Raymond $\mathrm{J}$. Stone as the main theory. In this theory, the variables of career planning and career management will be used as the guideline to obtain date from informants through in-depth interview. The process of career planning for individuals is expected to synergize with organization planning. Career management is carried out by the organization to achieve a meeting point between the individual's career plan and the planning and the development of a career managed by an organization to effectively achieve the goal of the organization.

Employee career is highly important for both individuals and the organization to achieve the goal of the organization [2] [3] [4]. That not all Indonesian government agencies consider the career of their employees by preparing an employee career plan [5]. This condition effects the dissatisfaction of the employees which in the end influences the performance of the organization. To manage the series of employee or individual positions, good management is required through career management in the organization. Career management is related to the open opportunities that are provided for employees to develop their career, and "Career management is concerned with the provision of opportunities for people to develop their abilities and their careers in order to ensure that the organization has the flow of talent it needs and to satisfy their own aspirations." [6]

Within career management, there are activities related to career development which are a series of long activities to realize and explore employee career and the success and fulfilment of employees' career. Career development is a formal approach carried out by an organization to assure that the employees in an organization meet the qualification and experience required by a position.

\section{METHOD}

To analyze the planning and guidance of employees' career in meeting the formation of the supervisor position in BKN, the author employs a post-positivist approach [7]. The Technique for Data Collection is the qualitative method through in-depth interview by proposing questions to informants before carrying out a study on the documents in which the data will be triangulated. The researcher in this matter is the key informant and the informants as the object of research are the employees who have met the general requirements to fulfil the formation of the supervisor position and have participated in the selection test of the supervisor position but have not yet passed the test and the informants from the HR management in BKN, which are the Head of the Employment Bureau and the personnel who directly handle HR management in BKN.

\section{RESULT}

For the employee career planning to be in line with the Stone theory, which includes the dimensions of self assessment, goal setting, career counseling, choice of job assignment, choice of job organization with the following results:

\section{a. Self Assessment}

Employees assess themselves to have the ability to meet the formation of the supervisor position, and the will of the employees is very strong because from several informants more than one participated in the selection for the formation of the supervisor position, but the fact is that these employees have not passed the test making self assessment unrealistic because in the end these informants do not have the right competence required for the formation of the Supervisor Position. This contradicts Mondy's theory stating that "self assessment is the process of learning about oneself. Realistic assessment may help a person avoid mistakes that could effect his or her career progression." [8]

\section{b. Goal Setting}

From the answers of the informants, both the employee informants who have not passed the test as well as the HR management in $\mathrm{BKN}$, they said that the employees are not consistent with their career purpose when faced with challenges from their initial career purpose to be in the supervisor position, and during the waiting period of the results of the test when there is another opportunity to fill in the position in the functional path, the employees take this opportunity and according to the employees this is more profitable because the extra allowance of the functional position and the extra allowance of performance are higher than the position of an executing officers. From the HR management there is no feedback towards the selection result of the employees who have not passed the test, or the competence of employees who have not passed the test is not evaluated in terms of the limitations because the results of the test are not announced. Employees who pass the test will find out when the inauguration is commenced. From the document study, in accordance with the Republic of Indonesia's Law Number 5 of the Year 2014 on ASN Article 71 it states that: 
(1) to assure the alignment of the potential of Civil Servants with the needs of carrying out governance and development, a Civil Servant career path which is nationally integrated is required; (2) every Government Agency composes a Civil Servant career path based on competence that is in accordance with the needs of the organization so that the determination of the employee career path is undirected.

\section{c. Career Counselling}

From the interview results with the informants, information is obtained that all the informants are aware that there is a career counsellor in $\mathrm{BKN}$ who is a psychologist, but the function of a career counsellor is to provide information on career and to provide advice to the employees to direct the planning and development of the employees' career; the Informants are not aware of this, and in planning their career the Informants did not receive any specific counselling from the organization. When reviewed from the regulation of the Head of BKN Number 19 of the Year 2014 on the organization and work plan of BKN Article 63 states that: "The Sub-Unit for Performance and Employee Counselling has the task to prepare the assessment materials for the performance and counselling for Employees' career." Thus, this unit has not carried out the task and function in accordance with the existing regulations and there have not been any meaningful actions done by the career management in BKN to improve the function of career counselling.

\section{d. Choice of Job Assignment}

From the results of the interview, information is obtained that employees have never conducted surveys on the various career options because the employees have never made a career opportunity map, and from the HR management in BKN until today there has not been any guidance or counselling in composing the career opportunity map, and career management in BKN has not yet determined the employee career path in accordance with competence. Career selection is still based on opportunities and chances that do not yet address the needs of the organization and subsequent career development for employees that is not yet planned and is not yet adjusted to the needs of the organization.

\section{e. Choice of Job Organization}

When deciding to select an organization and choosing to work in BKN, the informants who worked in BKN 20 years ago or longer never considered the issue of salary and career at that time, but because there was an opportunity to become a Civil Servant, and those people only aspired to work without thinking about career plans. The reason for employment is because being a Civil Servant allows the informants to be protected from employment discharge (PHK) and also because there is a guarantee of having a pension after retirement. The informants are also aware that the salary of a Civil Servant is not big. However, for informants who have worked in BKN since 5 years ago have begun to think about career plans and have decided to work in accordance with their education background based on the existing formation, and for career development there are many opportunities to continue education for free or with scholarship programs. According to a number of informants for the time being, BKN can be the purpose for a career, and there are even informants who recommend their children to work in BKN because there is a better career opportunity for employees who have at least an Undergraduate degree. For the reason that the career and salary are very good particularly in BKN with extra allowance for performance in an adequate amount.

In order to obtain information about career management, the researcher has conducted interviews with HR Management in BKN who handle employee career management particularly in filling the formation of the supervisor position in BKN.

\section{a. Recruitment and selection}

According to the HR management interviewed by the author, the regulations for the mechanism of the recruitment conduct and the selection for the supervision position are still absent, so for the conduct there has not been any clarity whether it is carried out every year or not and for the results of the test selection to be then carried out to an inauguration, for the supervisor position still does not have any standardization. After the selection test, for one year later or even more than one year, the employees who have passed the test are appointed to be put in the supervisor position.

\section{b. Performance Appraisal}

According to HR Management, Performance Assessment in BKN is conducted with the SKP (Employee Work Target) Assessment which essentially is the result of the position analysis of each position holder which has been agreed by 2 parties who include the assessed and the assessor. The way the performance assessment works is through stages from the staff who is assessed by the superior and so on. For SKP assessment, what is assessed is the activities related to positions and the work target which are quantity, quality, and also assessment for behavior. The results of SKP assessment will be one of the bases for assessment to participate in the selection for the formation of the supervisor position and are one of the administrative requirements that must be met. The assessment decision is based on the agreement in the beginning of the year when a task is commenced or when an employee joins a team or a working unit. However, regarding the determination of the performance achievement target, there has not been any fixed standard set by regulations so that the working target which has not been achieved cannot be easily sanctioned, as assessment can only be done on the basis of behavior. Regarding Performance Assessment, the Republic of Indonesia's Law Number 5 of the Year 2014 on Law ASN in Article 75 governs that the Performance Assessment of Civil Service seeks to guarantee objectivity of guiding Civil Servants based on an achievement system and a career system. In Article 76, it is mentioned that: (1) The performance assessment of Civil Servant is based on performance planning on the individual level and the unit level or organization, by considering the target, achievement, results, and benefits achieved, as well as the behavior of the Civil Servant. (2) Performance assessment of Civil Servants is conducted in a manner that is objective, measured, accountable, participatory, and transparent. 


\section{c. Assessment Center}

For the Assessment Center, an important aspect is the data on the education background and the data on the working experience of the employee managed by the Employment Bureau as the HR management in BKN and managed well in the form of an Employment Service Application System (SAPK) database which can be accessed online through the Internet network because the System is also integrated to the management of employee data throughout Indonesia but the management of it us under the Deputy for the Employment Information System. The Employment Bureau has the authority over the management of the internal data of employees in BKN. In the SAPK Application, there are data of education background of every employee in BKN and their working experience or position experience and the working unit of the employees from the beginning to the current status. This is already in accordance with the Republic of Indonesia's Law Number 5 of the Year 2014 on ASN Article 47 stating that: $\mathrm{BKN}$ has a function related to guiding the implementation of ASN Management, the implementation of ASN Management in terms of technical considerations on the formation, procurement, transfers among institutions, approvals for promotion, pension, and the recording of information for ASN Employees that have been finalized by the government agency whicn is made responsible over management and development of the ASN Information System.

\section{d. Skill Inventory}

Information on the Employee Skill Inventory in BKN is managed by the Employment Bureau in the form of a database and there is already an application for its management, which is the Employment Service Application System (SAPK) which is also integrated with the of all ASN Employees in Indonesia in accordance with the Regulation of the Head of BKN Number 14 of the Year 2011 on the Development of the System for Civil Servant (PNS) Database; in point 6 it mentions about SAPK: The Employment Service Application System which henceforth will be named SAPK is an employment service system that is integrated and connected online with all agencies to provice employment service.

\section{e. Career Ladder}

Career is about all role and responsibility of an employee during which the employee worked [9].In BKN, there are 2 career ladders which are the career in the structural track and the functional career track. For the structural position track, there are a number of levels of positions, which include the supervisor position, the administrator position, the Executive Leader position. In the functional position track, there are stages of specialist and skilled. For programs on individual career development, there are technical education and training programs held routinely in the unit of the Development Center in ASN and there are also study assignment and Education Assistance which are done in order to develop employees' competence. Employee promotion includes a number of criteria that must be met by an employee who will be promoted in accordance with the requirements that have been established. However, for the employee career track it has not yet to be set out by the organization so the position transfers from structural to functional or from functional to structural is not in accordance with employee competence and the needs of the organization. From the document study, the Republic of Indonesia's Law Number 5 of the Year 2014 on Law ASN in Article 13 states that the ASN Position consists of: (a) Administrative Position; (b) Functional Position; (c) Executive Leader Position. Then Article 14 explains that Administration Position as mentioned in Article 13 letter a consists of: (a) administrator position; (b) supervisor position; and (c) executing officer position.

\section{f. Succession Planning}

According to HR management in general, compiling data of future leaders or regeneration is in the working unit of each employee on Echelon 2 level because the leaders in these units are well versed on the daily performance of the employees in carrying out duties assigned by their superiors. The data from each unit will be collected in the Employment Bureau to compile data for the future leaders in Succession Planning. For leadership development training held every year, education and training programs are held, such as Public Speaking, Education and Training of Work Culture, Education and Training on Mind setting, and many others. Regarding the evaluation of the suitability between employees and positions, it can be observed from the performance assessment from the respective superiors, and the Employment Bureau will receive inputs from the head units for consideration of the rotation of the employees. The competence test of the future leader will be done during the position recruitment and selection. Education and training for employees who are in a position are called leadership education and training. In the Government Regulation Number 101 of the Year 2000 about the Education and Training Position for Civil Servants in Article 8 it is mentioned that: Education and Training Position is conducted to develop knowledge, skills, and behavior of Civil Servants in order to carry out government and development duties well.

\section{g. Outplacement}

According to HR management interviewed by the author, there are 2 types of employees who are terminated; namely they are terminated because of the Age Limit of Pension and terminated by the organization because of violation of regulations and subject to disciplinary sanction which is termination. The Education and Training for future Purna bakti or civil servants who are about to retire are carried out every year because every year there will always be employees who retire. For employees terminated because of disciplinary penalty, no counselling and education and training preparation for termination are given because the employees usually do not respond to invitations to the office. The education and training purna bakti usually contain information about preparation of skills for employees so that they can engage in favorable activities and can assist with the family's financial situation. According to the Head of Employment Bureau, career evaluation on the prediction of the number of employees who will enter purna bakti or pension is done as a preparation for the recruitment for the employee replacement program for a certain vacant position or for the needs of new employee recruitment.

The data that are obtained in the field are for career evaluation and suggestions to carry out the termination 
procedure or pension in BKN which has been done, and for psychological assessment for employees who will enter pension through BUP or normal because of age there are education and training programs and motivations provided, but for employees who are terminated because of disciplinary violation they are not provided. Techniques on job seeking in the education and training program provide skills on entrepreneurship.

\section{CONCLUSION}

Based on the results of the analysis as elaborated previously, it can be concluded that: (1) there is not yet alignment between Career Planning and Career Management in the State Employment Agency, employee career planning is unplanned and does not have a clear career purpose because career management in BKN does not set out an employee career path that is in accordance with qualification and competence. The career management in BKN has not composed an employee career pattern that is in accordance with the potential of the employees and the needs of the organization; (2) the planning and development of employees' career to fill in the formation of the supervisor position in the State Employment Agency are not in accordance with the individuals' career plan and the organization's career plan, and the employees do not plan their career to fill the formation of the supervisor position but only to partake in any opportunity so that if organization planning to fill in the formation of the supervisor position is not met, as the self assessment of the individual employee is not in accordance with the competence of the employee to meet the standard of the competence of the supervisor position. However, the competence standard of the position does not yet exist. Employees do not have commitment to their career purpose because there is no career counselling which provides advice and directions on individual employees' career planning, there are no norms, no operational standards, and fixed procedures during filling the formation of the supervisor position, especially in the recruitment and selection mechanism. The Development Program of employees' career does not yet support employees' need to improve competence which is in accordance with the needs of the organization, so no accurate target can be given to increase the competence of employees in filling the formation of the supervisor position and increase the benefits for the organization.

The researcher's suggestions towards the problem related to planning and development of employees' career in filling the formation of the supervisor position in the State Employment Agency are : (1) the State Employment Agency needs to compose an individual career plan for employees that is in accordance with the career plan of the organization and an employee career pattern system needs to be set up based on the mandate given in the Republic of Indonesia's Law Number 5 of the Year 2014 about Civil Servants in Article 71 about career patterns: (1) to assure the alignment of the potential of Civil Servants with the needs of carrying out government duties and development a Civil Servant career plan must be composed and is nationally integrated; (2) every Government Agency must compose a specific Civil Servant career plan that is in accordance with the needs based on the national career pattern; (2) BKN needs to establish norms, operational standards, and fixed procedures in filling the formation of the supervisor position, particularly on the recruitment and selection mechanism; (3) BKN needs to improve the function of career counselling which is existent but does function as it should, which is to provide information and advice to employees to direct their career plan and development; (4) evaluation of the filling of the formation of the supervisor position and other structural positions needs to be done every year because the fact is the Supervisor Position has been vacant for more than 2 years.

\section{ACKNOWLEDGMENT}

This article is part of a publication from a final assignment and is funded with the help of PITTA Fund from Universitas Indonesia.

\section{REFERENCES}

[1] Stone, Raymond J, (2010), Human Resource Management,John Wiley \& Sons Inc, Australian Human Resource Institute (AHRI)

[2] Byars, Lloyd L. \& Rue, Leslie W, (2006), Human Resource Management, 8th edition,McGraw-Hill, (terjemahan Alponso S. Erlangga,Jakarta)

[3] Mondy, R.Wayne and Robert M Noe (2010), Human Resources Management, Ninth Edition, Pearson Prentice Hall

[4] Noe, Raymond A, Hollenbeck, John R., Gerhart, Barry and Wright Patrick M., (2003) Human Resources Management, Mc-Graw-Hil Irwin,

[5] Wirawan (2015), Manajemen Sumber Daya Manusia, Raja Grafindo Persada,Jakarta

[6] Amstrong, Michael (2009), Amstrong's Handbook of Human Resource Management Practice, 11th Edition, Kogan Page, London-UK Burack, Elmer H, Mathys, Nicholas J, (1996), Human Resource Planning : A Pragmatic Approach to Manpower staffing and Development,

[7] Creswell, John W,(2009) Research Design (Third Edition), SAGE Publications,USA.

[8] NY Mathis, Robert L, John Jackson (2002), Manajemen Sumber Daya Manusia, edisi pertama, Salemba empat, Jakarta

[9] Siagian, P Sondang (2011), Manajemen Sumber Daya Manusia, Bum Aksara, Jakarta Statistik PNS Badan Kepegawaian Negara bulan Desember 2012, BKN,Jakarta 